\title{
Utilization of Siam Weed leaves (Chromolaena odorata L.) as natural dyes
}

\author{
Dulmalik $^{1, *}$, Selli Rosliani², Sella Rosliana ${ }^{3}$ \\ ${ }^{1,2,3}$ Study Program of Chemical Engineering, Islamic University of Indonesia, Yogyakarta 55584, Indonesia \\ E-mail:815210102@uii.ac.id * \\ *Corresponding Author
}

\begin{tabular}{|c|c|}
\hline ABSTRACT & ARTICLE INFO \\
\hline $\begin{array}{l}\text { Siam Weed leaves can be used as natural dyes since they contain tannin } \\
\text { compounds which give a brown color to the dyeing of fabrics. This study was } \\
\text { conducted to utilize Siam Weed leaves as a natural dye substitute for synthetic } \\
\text { cotton cloth and obtain dye from Siam Weed leaves in liquid form. The material } \\
\text { used is a dyed cotton cloth with the extract of Siam Weed leaves. The variation } \\
\text { of dipping time was } 30 \text { minutes and } 13 \text { hours. The types of fixators used were } \\
\text { Ferrous Sulfate and Alum solution. The findings showed that the type of fixator } \\
\text { can affect the color result of the fabric. The fixed fixator produces a dark green } \\
\text { color while the Alum solution produces a yellow color. Based on the results of } \\
\text { the dry rub test, the cloth that has been immersed in the dye for } 13 \text { hours and } \\
\text { fixed by an Alum fixator produces the maximum color fastness value with a } \\
\text { staining scale value of } 5,5 \text {, } 5 \text { (very good). Whereas in the wet rub test, the cloth } \\
\text { that has been immersed in the dye for } 13 \text { hours and fixed with an Alum solution } \\
\text { fixator produces good values with a range of values for the staining scale } 4-5 \text {, } 4- \\
5,4-5 \text { (good). In the colorfastness test of washing cloth soap soaked for } 30 \\
\text { minutes, the best dye fastness with a grayscale value of } 4-5,4-5,4-5 \text { (good). The } \\
\text { type of fixator that has the best colorfastness in the washing test is the Alum } \\
\text { fixator. }\end{array}$ & $\begin{array}{r}\text { Article history } \\
\text { Received: } \\
2 \text { July } 2021 \\
\text { Revised: } \\
10 \text { August } 2021 \\
\text { Accepted: } \\
13 \text { August } 2021 \\
\\
\text { Keywords } \\
\text { Tack } \\
\text { Tannins } \\
\text { Natural Dyes } \\
\text { Cotton } \\
\text { Fixation }\end{array}$ \\
\hline $\begin{array}{l}\text { This is an open-access article under the CC-BY-SA license. } \\
\text { (C) (D) (O) }\end{array}$ & \\
\hline
\end{tabular}

\section{Introduction}

As health and environmental science progresses, it is becoming clear that the use of synthetic dyes has serious health consequences [1], [2]. Long-term exposure to azo dyes (applied naphthol and diazo) can result in cancer, and also damaging towards the kidneys and liver [3]. In addition, synthetic dye waste can cause environmental pollution and is a hazardous material because some dyes can be classified as carcinogenic and toxic compounds [4]-[6].

Synthetic dyes can be substituted with natural dyes [7]-[9]. Natural dyes are non-toxic, renewable, and easily graded dyes which are also environmentally friendly [10]. Natural textile dyes are tacked plants. The leaves contain several main compounds such as tannins, phenols, flavonoids, saponins, and steroids [11]. The essential oils from the leaves contain -pinene, cadinene, camphora, limonene, $\beta$-caryophyllene, and candinol isomer [12]. 
In this study, dyeing from Siam Weed leaves was used for quality of primissima fabric material [13]. The reason for using Siam Weed leaves is because they contain an alkaloids, shaponi, metasalicylate, polyromic, saffron, flavonoid, and polyphenol. Its flower contains mythanthine. This Oleaceae familia has a bitter character and astringent [7]. Fig. 1 shows Siam Weed leaves.
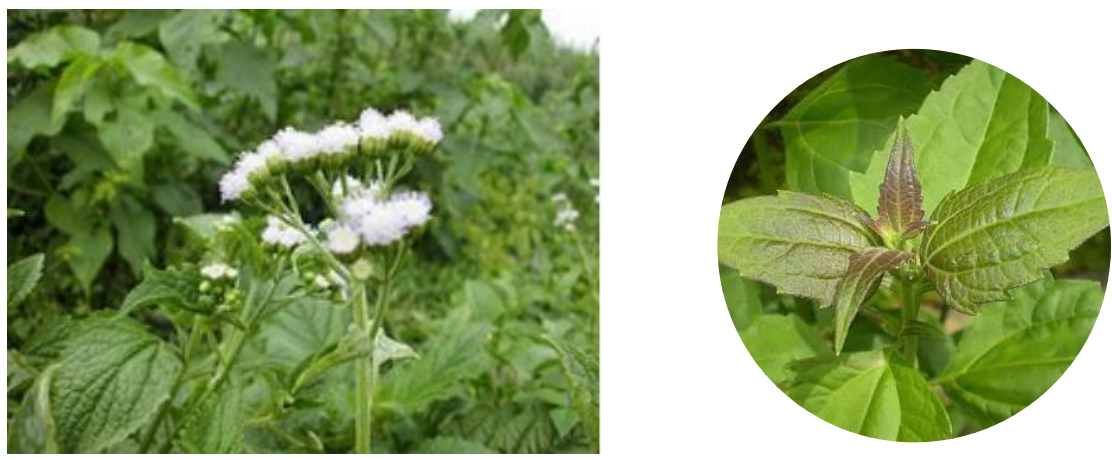

Fig. 1. Siam Weed leaves

It was intended to make use of existing natural resources, produce environmentally friendly dyes that are less harmful to the environment than synthetic dyes, and eliminate hazardous waste that can harm the ecosystem [14]. Siam weed plants can be propagated from seed or cuttings. Siam Weed is a relatively high-maintenance plant. This plant requires plenty of sunlight and a well-protected environment [15].

\section{Research Method}

This study was conducted at the laboratory of process chemistry, Faculty of Industrial Technology, the Islamic University of Indonesia, and the textile evaluation laboratory, Faculty of Industrial Technology, Islamic University of Indonesia.

\subsection{Research Procedure}

The Extraction process of Siam Weed leaves [16] is presented in Fig.2.

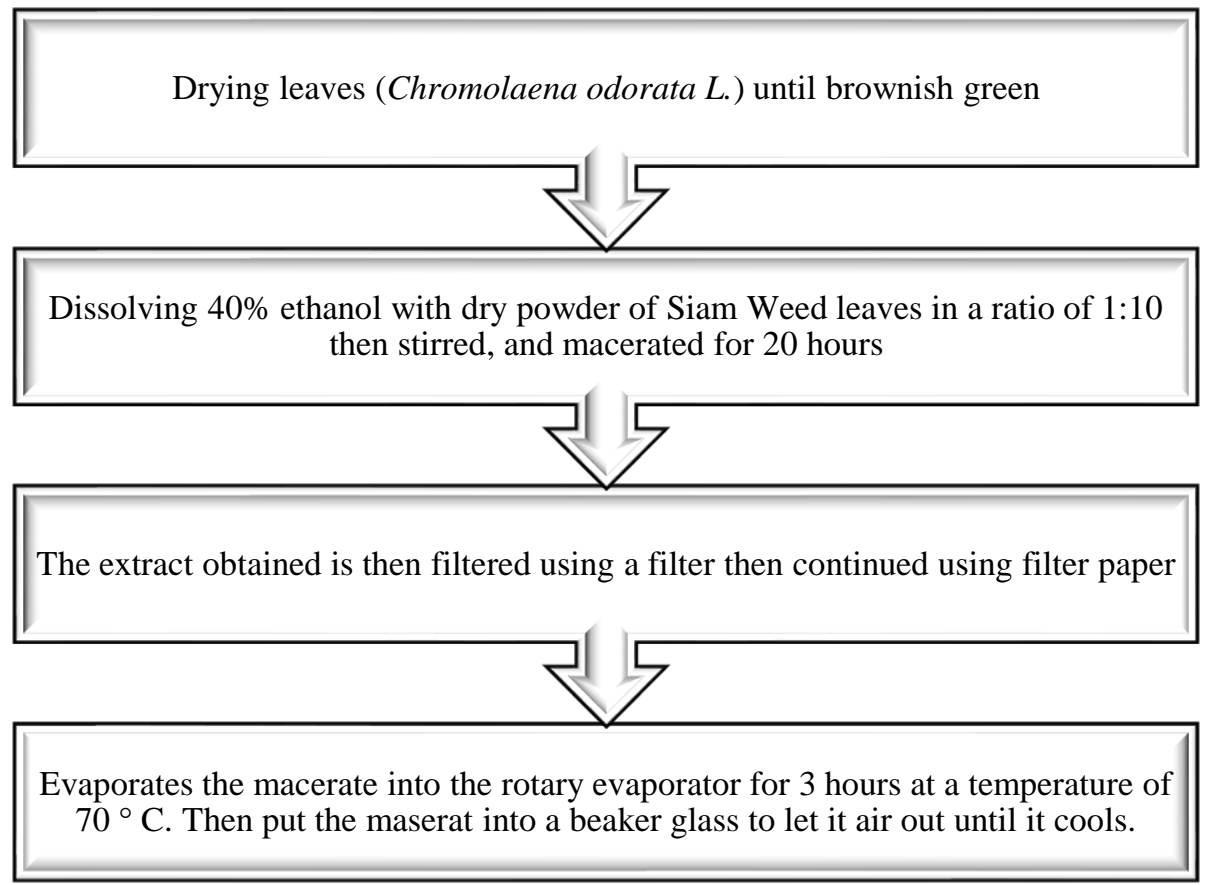

Fig. 2. Extraction process for Siam Weed leaves 
Fig. 3 illustrates the determination of the extraction content of the Siam Weed leaves dyestuff.

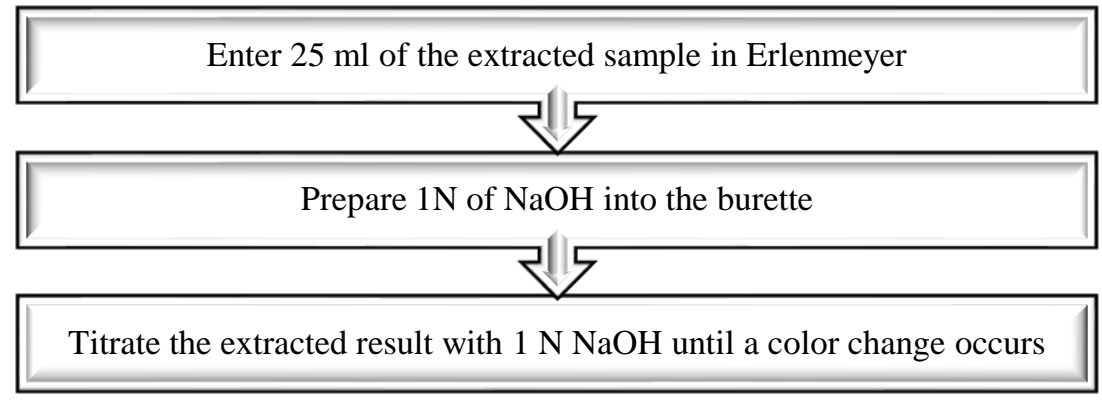

Fig. 3. Determination of extraction content of leaves dye in Siam Weed

Mordanting process is described in Fig.4, while the dyeing process is presented in Fig.5.

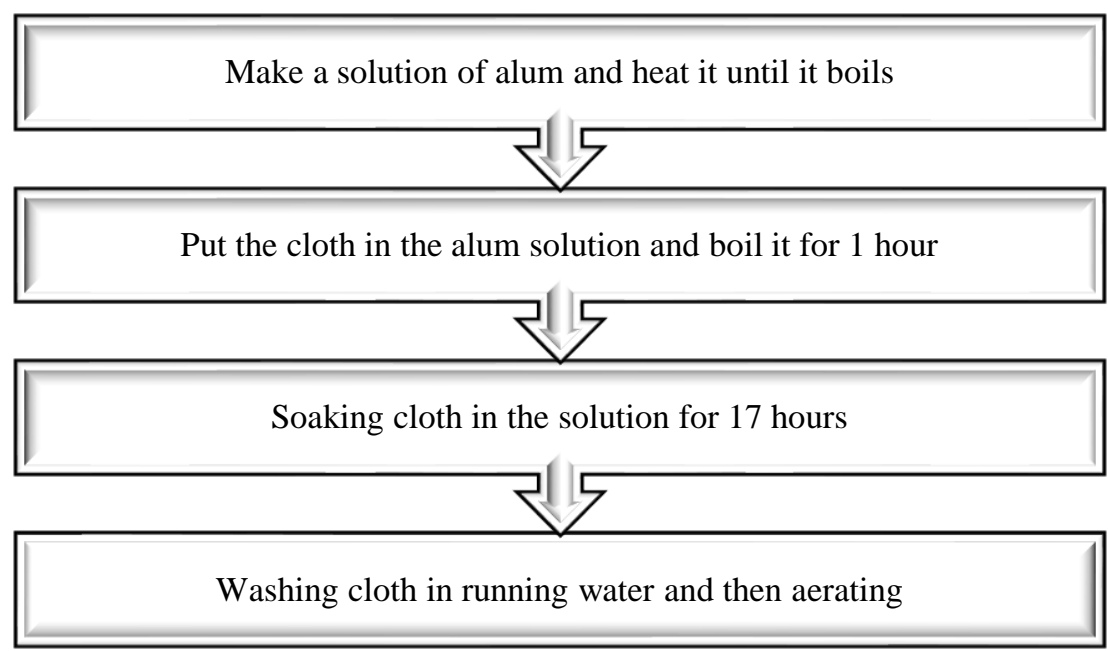

Fig.4. Mordanting process

Dipping the mordant cloth in the dye solution with a predetermined time duration
of 30 minutes and 13 hours with different dyeing processes ( 1 and 3 times).

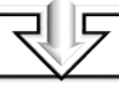

Clothes that have been immersed in the dye solution for 13 hours are only coloured once, wrapped, and dried out of direct sunlight.

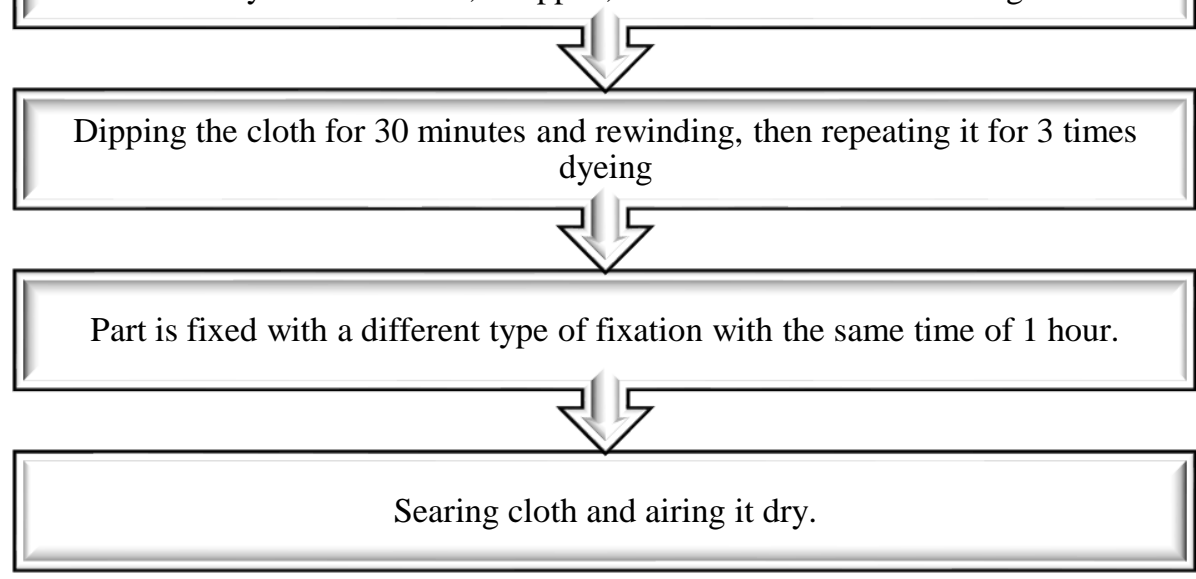

Fig. 5. Dyeing process 
Fig. 6 shows the color test [17] and color fastness test using the washing soap method is presented in Fig.7.

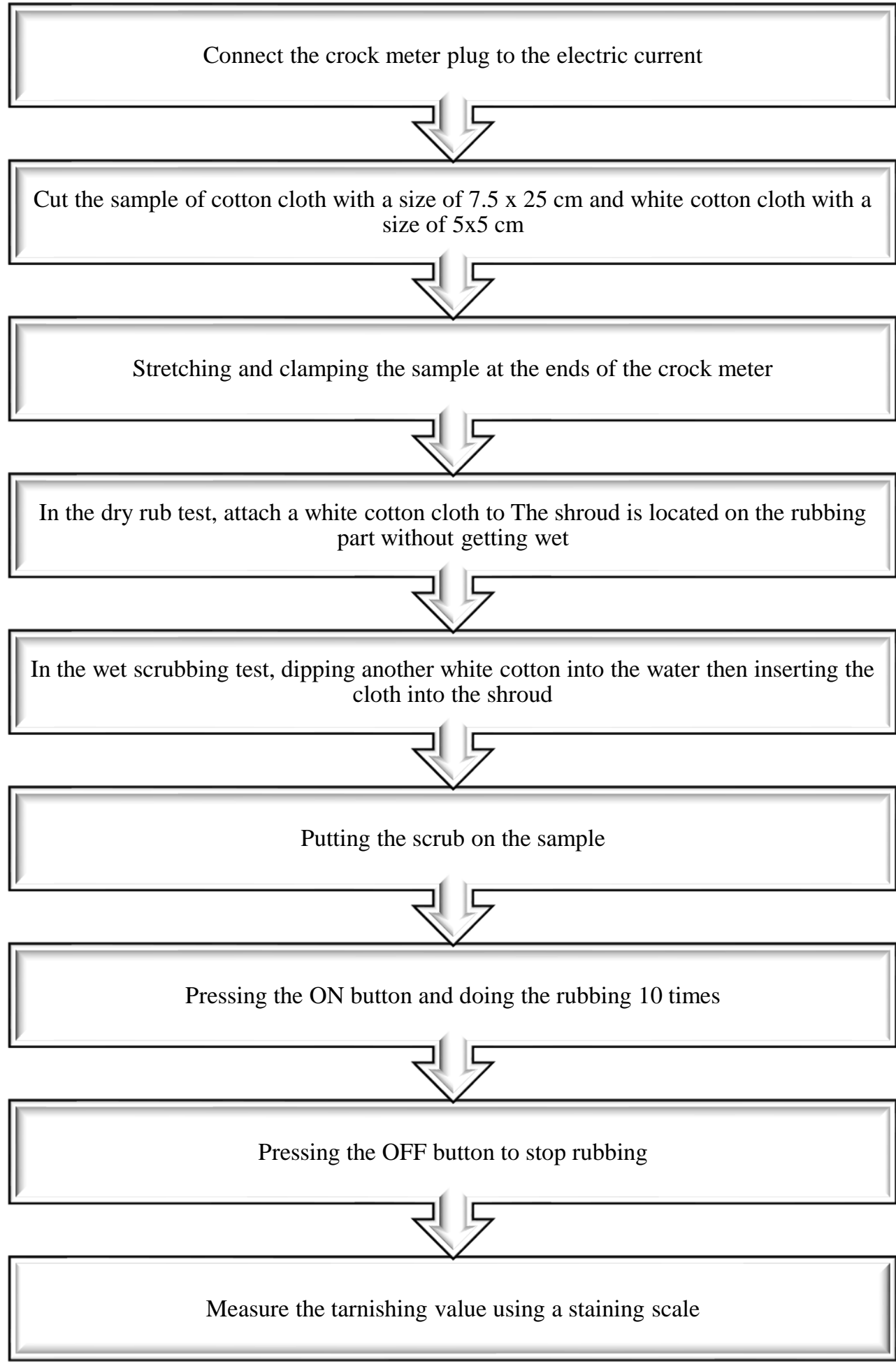

Fig. 6. Color fastness test 


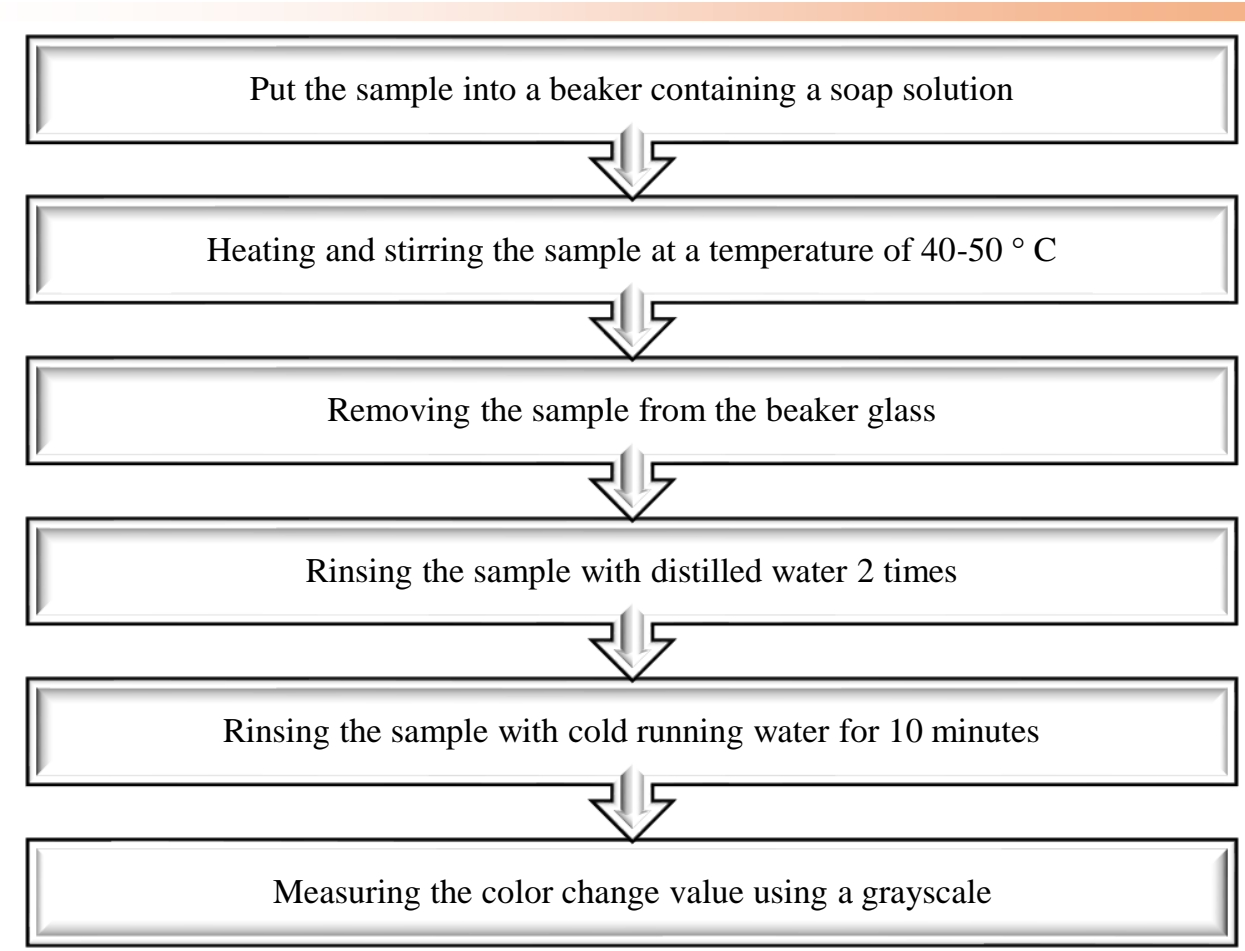

Fig.7. Washing soap fastness test

\subsection{Research Sample Preparation}

The research sample preparation [7] is as follows:

(1) The extraction process of Siam Weed leaves

The Siam Weed (C. odorata) leaves simplicia was extracted using the maceration method. $500 \mathrm{~g}$ of Siam Weed leaves powder was extracted with 5 liters of $40 \%$ ethanol for 20 hours. The extract obtained was filtered, then re-filtered with filter paper. The extraction was carried out by evaporating using a rotary evaporator for 3 hours at a temperature of $70^{\circ} \mathrm{C}$ so that a thick extract was obtained as illustrated in Fig.8.

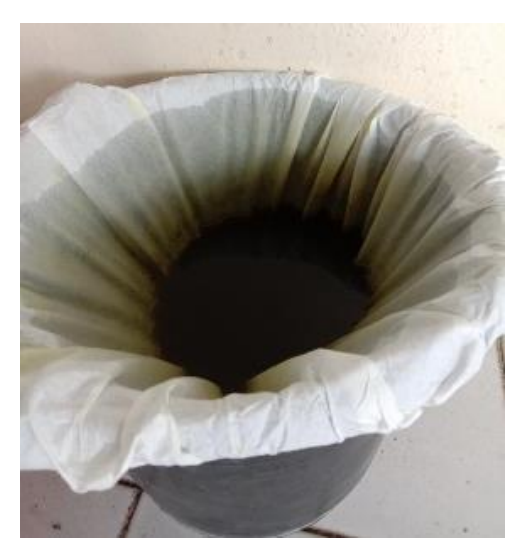

Fig. 8. The extraction process

(2) Determination of leaf dye levels in the extraction process

Take $25 \mathrm{ml}$ of the extracted sample and put it in Erlenmeyer, then titrate the results of the sample with $1 \mathrm{~N} \mathrm{NaOH}$ until the color changes as explained in Fig.9. 


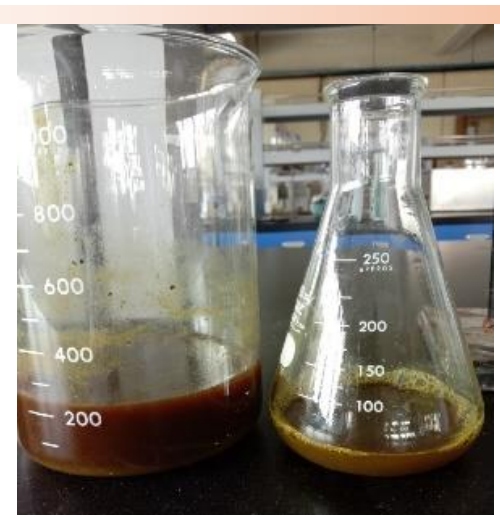

Fig.9. Determination of leaf dye

(3) Mordanting process

Put 24 grams of Alum solution into 3 liters of water, heat it on the stove and stir until the Alum solution is completely dissolved. Cut the cotton cloth as needed, put the cotton cloth in the alum solution, boil for up to 1 hour after that, turn off the heat. Soak a cotton cloth in the solution for 17 hours. Then, remove the cloth and rinse under running water (without wringing it out), dry (not exposed to direct sunlight), and then iron the cloth. See Fig.10.

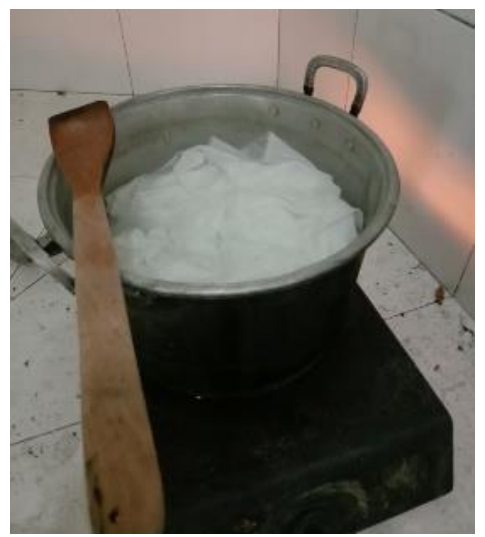

Fig. 10. Mordanting process

(4) Dyeing process

Dip the mordant cloth in the dye solution for 30 minutes and 13 hours, respectively, with different dyeing methods ( 1 and 3 times). The cloth (sample 1) was immersed once for 13 hours, wrapping the cloth dry without direct sunlight. Dipping the cloth (sample 2) for 30 minutes and rewarming, this was repeated 3 times dyeing. Each fabric sample was fixed with a different type of fixation, the type of fixation used was Alum solution and Ferrous Sulfate, each as much as 30 grams. As much as 30 grams of Alum solution and Ferrous Sulfate fixation materials were dissolved into 3 liters of aquadest. Each cloth sample was fixed with the same duration of time, namely 60 minutes. Sear the fabric and let it dry. It is presented in Fig.11. 


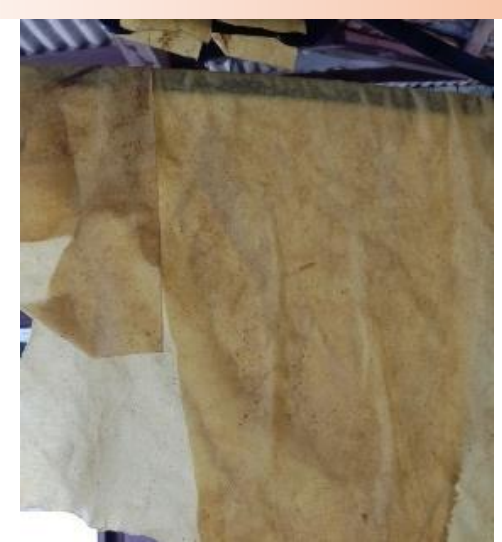

Fig.11. Dyeing process

(5) Color fastness test using the cloth rub method (crockmeter)

The first step is to connect the crock meter socket to an electric current source. The colored fabric test sample is cut according to the provisions with a size of $7.5 \times 25 \mathrm{~cm}$ and white cotton cloth is cut as standard with a size of $5 \times 5 \mathrm{~cm}$. At the crock meter's ends, the cloth is stretched and clasped. On the rubbing section, attach a $5 \times 5 \mathrm{~cm}$ white fabric to the current sheath.

Different treatments, such as the dry scrubbing test and the wet rubbing test, were used during the testing process. In the dry rub test, a $5 \times 5$ white cotton cloth is inserted into the rubbing section tube without getting wet, whereas in the wet rub test, a $5 \times 5 \mathrm{~cm}$ white cotton cloth is wetted by dipping it in water and then drying it with a tissue so that the condition is still damp, after which the cloth is removed. After the cloth is attached, this is placed into the shroud in the rubbing area, rubbing 10 times, and assessing the rubbing result using a staining scale. See Fig. 12.

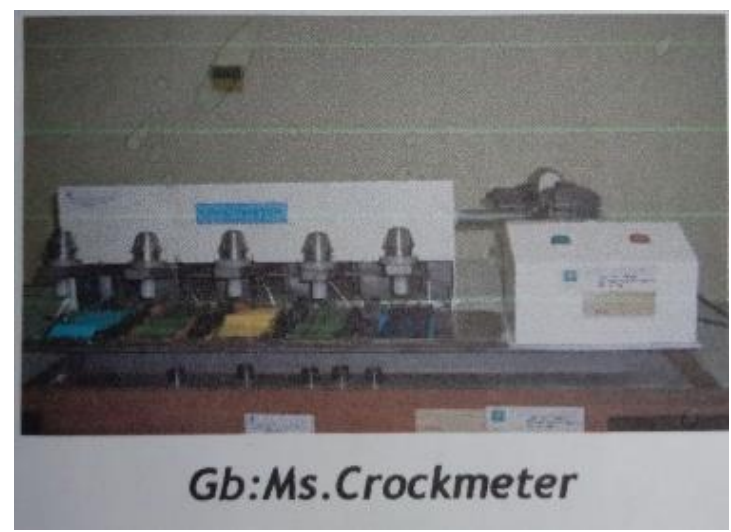

Fig. 12. Color fastness test

(6) Color fastness test using the washing soap method

Place the test sample in a beaker with a detergent solution of $5000 \mathrm{ppm}$. Then, at a temperature of 40-50 degrees Celsius, heat and agitate the sample for 30 minutes. When stirring by hand, the sample is rubbed against the beaker's wall every two minutes without being taken out of the solution. The sample is then removed from the beaker and rinsed with cold running water for 10 minutes before being pressed for the next step, which is to 
use a grayscale measuring instrument to determine the value of the color shift. Fig. 13 depicts the situation.

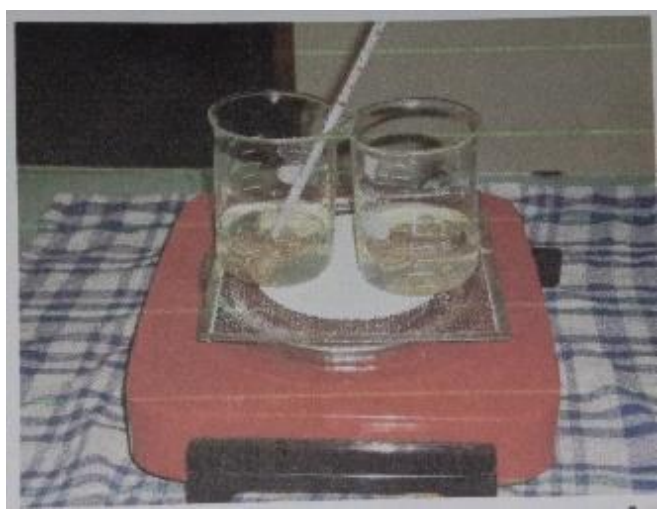

Fig. 13. Washing soap method

\section{Result and Discussion}

\subsection{Levels of the Extract of the Dye Leaves of the Siam Weed}

Siam Weed Leaves extract has a distinctive odor and a brown color. Extraction was carried out using the maceration method resulting in an extract of $250 \mathrm{ml}$. In addition, a titration was performed with the goal of determining the dye concentration. Titration was done with a $1 \mathrm{~N}$ $\mathrm{NaOH}$ solution until the color changes from brown to brass.

\subsection{The Effect of Dyeing Time on Cotton Fabrics}

Table 1 shows that the length of the dyeing process affects the uniformity of the color on the fabric and the age of the color obtained. The longer it is used, the more evenly the color will be on the fabric and the darker the color will be. Table 2 shows dyeing in the fixation process.

Table 1. Dye absorption sample immersion

\begin{tabular}{|c|c|}
\hline \multicolumn{2}{|c|}{ Time } \\
\hline $\begin{array}{r}\text { Sample I } \\
(30 \text { minutes })\end{array}$ & $\begin{array}{c}\text { Sample II } \\
\text { (13 hours) }\end{array}$ \\
\hline & \\
\hline & \\
\hline & \\
\hline
\end{tabular}

Table 2. Dyeing in the fixation process

\begin{tabular}{|c|c|c|}
\hline \multirow[t]{2}{*}{ Immersion } & \multicolumn{2}{|c|}{ Type of fixation } \\
\hline & Alum solution & Ferrous Sulfate \\
\hline $\begin{array}{l}60 \text { minutes (sample } 1 \\
\text { immersion } 30 \text { minutes) }\end{array}$ & & \\
\hline $\begin{array}{l}60 \text { minutes (sample } 2 \\
\text { immersion } 13 \text { hours) }\end{array}$ & & \\
\hline
\end{tabular}


The type of fixator affects the resulted color direction, namely, the Alum solution fixator produces a bright yellow color, while the fixed fixator produces a dark green color.

\subsubsection{Color Resistance Test Against Cloth Rubbing (Greyscale and Staining Scale)}

Colorfastness assessment of textiles is carried out by observing any changes in the original color of the test sample as unchanged, there is little change and completely changed. Based on the research, the dry and wet testing can be presented in Table 3 and Table 4.

Table 3. Dry rub test

\begin{tabular}{|c|c|c|c|}
\hline \multirow[t]{2}{*}{ Sample code } & \multicolumn{3}{|c|}{ Test } \\
\hline & 1 & 2 & 3 \\
\hline $\begin{array}{l}\text { Ferrous Sulfate } \\
30 \text { minutes }\end{array}$ & $4-5$ (good) & $4-5$ (good) & $4($ good $)$ \\
\hline $\begin{array}{l}\text { Alum solution } \\
30 \text { minutes }\end{array}$ & $4-5$ (good) & $4-5$ (good) & $4-5$ (good) \\
\hline $\begin{array}{l}\text { Alum solution } \\
13 \text { hours }\end{array}$ & 5 (very good) & 5 (very good) & 5 (very good) \\
\hline $\begin{array}{c}\text { Ferrous Sulfate } \\
13 \text { hours }\end{array}$ & 5 (very good) & 4-5 (good) & $4-5$ (good) \\
\hline
\end{tabular}

The colorfastness test gives diverse results, as can be seen from the data shown. The colorfastness test on the wet rubbing test with an Alum solution fixator over a period of 13 hours yielded a maximum value of 5, 5, 5 on the staining scale (very good).

Table 4. Wet rub test

\begin{tabular}{cccc}
\hline Sample Code & \multicolumn{3}{c}{ Test } \\
\cline { 2 - 4 } & $\mathbf{1}$ & $\mathbf{2}$ & $\mathbf{3}$ \\
\hline Ferrous Sulfate & 4 (good) & $3-4$ (good enough) \\
30 minutes & $3-4$ (good enough) & $4-5$ (good) & $4-5$ (good) \\
$\begin{array}{c}\text { Alum solution } \\
30 \text { minutes }\end{array}$ & 4 (good) & $4-5$ (good) & $4-5$ (very good) \\
$\begin{array}{c}\text { Alum solution } \\
13 \text { hours }\end{array}$ & $4-5$ (good) & 4 (good) & 4 (good) \\
$\begin{array}{c}\text { Ferrous Sulfate } \\
13 \text { hours }\end{array}$ & $4-5$ (good) & &
\end{tabular}

The wet cloth rubbing test on each fabric sample provides various colorfastness test values, as can be seen from the data provided. With a staining scale value of 4-5, 4-5, 4-5(good), the color fastness test value on the wet rubbing test using an Alum solution fixator with a time of 13 hours provided the highest results.

\subsubsection{Wash Fastness}

The color fastness test of washing soap in this study was carried out 3 times and assessed using a grayscale. The results are presented in Table 5. From the data above, it can be seen that the value of the colorfastness test for washing soap from two types of fixators with differences in dyeing time on the fabric each has a different grayscale value. The value of the colorfastness test for washing soap using an Alum solution fixator with a time of 30 minutes is the best with a grayscale value of 4-5, 4-5, 4-5 (good). 
Table 5. Wash fastness test

\begin{tabular}{ccc}
\hline Sample code & Test & $\begin{array}{c}\text { TLW test value for washing } \\
\text { soap }\end{array}$ \\
\hline A & 1 & $3-4$ (good enough) \\
Ferrous Sulfate & 2 & $3-4$ (good enough) \\
30 minutes & 3 & $3-4$ (good enough) \\
B & 1 & $4-5$ (good) \\
Alum solution & 2 & $4-5$ (good) \\
30 minutes & 3 & $4-5$ (good) \\
C & 1 & 4 (good) \\
Alum solution & 2 & 4 (good) \\
13 hours & 3 & 4 (good) \\
D & 1 & 3 (enough) \\
Ferrous Sulfate & 2 & 3 (enough) \\
13 hours & 3 & 3 (enough) \\
\hline
\end{tabular}

\section{Conclusion}

The color produced by the Siam Weed leaves extract was determined to be brown based on the study's findings. The second finding is that varied lengths of time for dyeing can impact color consistency. On cotton cloths, dyeing for 30 minutes resulted in uneven colors, but dyeing for 13 hours resulted in an even color. Furthermore, the employment of various fixators resulted in a variety of colors. The light-yellow cloth turned dark green after being fixed with ferrous sulfate, and the dark yellow cloth became dark yellow after being fixed with alum.

\section{References}

[1] A. D. Khaliq, A. Chafidz, F. I. Rahmillah, M. I. Masruri, and H. D. Hutama, "Practical aplication of reinforcement remazol dyes on cotton material using fixation abu ash and amylum," Journal of Physics: Conference Series, vol. 1833, no. 1, p. 012015, Mar. 2021, doi: 10.1088/1742-6596/1833/1/012015.

[2] Suciatmih, Nurfianti, and S. V Magfirani, "Coloring properties assessment of dyes produced by mixed Aspergillus and Paecilomyces," IOP Conference Series: Earth and Environmental Science, vol. 166, no. 1, p. 012023, Jun. 2018, doi: 10.1088/17551315/166/1/012023.

[3] A. D. Khaliq, A. Chafidz, F. I. Rahmillah, W. N. Dahliani, and Y. N. Iffah, "Practical aplication of reinforcement of remazol dyes substance on the quality of cotton material using fixation waterglass," IOP Conference Series: Materials Science and Engineering, vol. 722, no. 1, p. 012070, Jan. 2020, doi: 10.1088/1757-899X/722/1/012070.

[4] T. Pujilestari, "Review: Sumber dan Pemanfaatan Zat Warna Alam untuk Keperluan Industri," Dinamika Kerajinan dan Batik: Majalah Ilmiah, vol. 32, no. 2, pp. 93-106, Jun. 2016, doi: 10.22322/DKB.V32I2.1365.

[5] T. Pujilestari, F. Farida, E. Pristiwati, A. Haerudin, and V. Atika, "Pemanfaatan zat warna alam dari limbah perkebunan Kelapa Sawit dan Kakao sebagai bahan pewarna kain batik," Dinamika Kerajinan dan Batik: Majalah Ilmiah, vol. 33, no. 1, pp. 1-8, Jun. 2016, doi: 10.22322/DKB.V33I1.1119.

[6] R. Kant, "Textile dyeing industry an environmental hazard," vol. 2012, no. 01, pp. 22-26, 
Dec. 2011, doi: 10.4236/NS.2012.41004.

[7] D. Suheryanto, Natural Dyes, Ensiklopedia Zat Warna Alami dari Tumbuhan untuk Industri Batik. Yogyakarta: Andy Publishing, 2017.

[8] P. Kaššák and K. Kaffková, "Usage of Tagetes and Tanacetum as dye plants for natural and artificial fibers," Open Agriculture, vol. 3, no. 1, pp. 291-295, Aug. 2018, doi: 10.1515/OPAG-2018-0031.

[9] Y. Zhang, Q. Zhou, L. J. Rather, and Q. Li, “Agricultural waste of Eriobotrya japonica L. (Loquat) seeds and flora leaves as source of natural dye and bio-mordant for coloration and bio-functional finishing of wool textile," Industrial Crops and Products, vol. 169, p. 113633, Oct. 2021, doi: 10.1016/J.INDCROP.2021.113633.

[10] T. Pujilestari, "Optimasi pencelupan kain batik katun dengan pewarna alam tingi (Ceriops Tagal) dan Indigofera Sp,” Dinamika Kerajinan dan Batik: Majalah Ilmiah, vol. 34, no. 1, pp. 53-62, Jun. 2017, doi: 10.22322/DKB.V34I1.2606.

[11] E. Kwartiningsih, D. A. Setyawardhani, A. Wilyanto, and A. Triyono, "Zat pewarna alami tekstil dari kulit buah Manggis," Ekuilibrium [, vol. 8, no. 1, pp. 41-47, Mar. 2009, doi: 10.20961/EKUILIBRIUM.V8I1.49518.

[12] E. Kismolo, M. Isman, and Nurimaniwathy, "Reduksi volume limbah uranium cair fase air menggunakan Rotavapor," in Prosiding Pertemuan dan Prescnlasi Ilmiah PPNYBATAN Yogyakarta25-27Aprii, 1995, pp. 285-288.

[13] L. Maghfiroh and W. Widowati, "Kualitas hasil pencelupan kain mori primissima menggunakan limbah kulit buah Naga Merah," Fashion and Fashion Education Journal, vol. 9, no. 2, pp. 70-77, 2020, doi: 10.15294/FFEJ.V9I2.37371.

[14] A. D. Khaliq, A. Chafidz, F. R. Maddun, H. R. Herimawan, G. M. Yusuf, and F. I. Rahmillah, "The use of hydrogen peroxide and sky stabilizer agent in bleaching process of textile fabrics," AIP Conference Proceedings, vol. 2138, no. 1, p. 050011, Aug. 2019, doi: 10.1063/1.5121116.

[15] M. Triyana, "Effect of Kirinyuh Leaf Extract ( Chromolaena Odorata [L])," Padang, 2018.

[16] A. F. Faputri, "Desain evaporator dan pengujian kondisi operasi optimal pada desain peralatan [Evaporator Design and Testing of Optimal Operating Conditions on Equipment Design]," Jurnal Teknik Patra Akademika, vol. 7, no. 02, pp. 17-22, 2016, Accessed: Aug. 20, 2021. [Online]. Available: http://jurnal.pap.ac.id/index.php/JTPA/article/view/15.

[17] W. Murdoko, Evaluasi Tekstil. Bandung: Institut Teknologi Tekstil Bandung, Indonesia., 2016. 